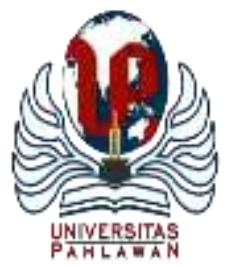

Edukatif : Jurnal Ilmu Pendidikan Volume 3 Nomor 6 Tahun 2021 Halm 4689 - 4699

EDUKATIF: JURNAL ILMU PENDIDIKAN

Research \& Learning in Education

https://edukatif.org/index.php/edukatif/index

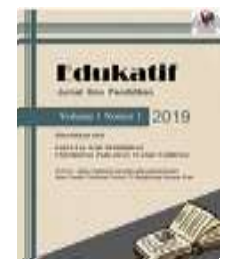

\title{
Kepemimpinan Merek pada Website E-commerce: Analisis Pengaruhnya terhadap Niat Pembelian Ulang
}

\author{
Nuri Wiyono $^{1 凶}$, Siti Abadiyah ${ }^{2}$, Dwi Ferdiyatmoko Cahya Kumoro ${ }^{3}$, Masduki Asbari ${ }^{4}$, \\ Dewiana Novitasari ${ }^{5}$ \\ STMIK Insan Pembangunan, Indonesia ${ }^{1,4}$ \\ Universitas Muhammadiyah Tangerang, Indonesia ${ }^{2}$ \\ Sekolah Tinggi Ilmu Ekonomi Insan Pembangunan, Indonesia ${ }^{3,5}$ \\ E-mail : nwiyono.ip@gmail.com ${ }^{1}$, abadidede01@yahoo.com ${ }^{2}$, ferdi dede12@yahoo.com ${ }^{3}$, \\ kangmasduki.ssi@gmail.com ${ }^{4}$, dhewiediosa@ yahoo.co.id ${ }^{5}$
}

\begin{abstract}
Abstrak
Tujuan dari studi ini adalah untuk menyelidiki pengaruh kepemimpinan merek (yang terdiri dari dimensi kualitas, nilai, inovasi, dan popularitas) yang dirasakan oleh konsumen dari sebuah situs web e-commerce terhadap niat pembelian ulang di kalangan mahasiswa perguruan tinggi swasta. Sampel penelitian ini diambil dari 1026 mahasiswa dengan teknik simple random sampling dan menggunakan SEM (Structural Equation Model) dengan software SmartPLS versi 3.0 sebagai alat bantu statistik. Hasil dari penelitian ini menunjukkan bahwa seluruh dimensi kepemimpinan merek berpengaruh positif dan signifikan terhadap niat pembelian ulang. Dimensi popularitas memiliki pengaruh paling besar untuk mendorong niat pembelian ulang di situs ecommerce. Kemudian diikuti oleh dimensi kualitas, inovasi dan dimensi nilai. Studi ini mencatat bahwa konsumen memiliki opini yang tinggi terhadap merek-merek terkemuka bahkan ketika merek tersebut belum terbukti memberikan produk berkualitas tinggi. Ulasan online dan ulasan dari mulut-ke mulut dapat digunakan untuk meningkatkan dan mempertahankan popularitas, yang dapat membangun kepercayaan terhadap produk.
\end{abstract}

Kata kunci: E-commerce, kepemimpinan merek, niat pembelian ulang.

\begin{abstract}
This study aims to investigate the effect of brand leadership (consisting of the dimensions of quality, value, innovation, and popularity) perceived by consumers of an e-commerce website on repurchase intentions among private college students. The sample of this research was taken from 1026 students using a simple random sampling technique and using SEM (Structural Equation Model) with SmartPLS software version 3.0 as a statistical tool. The results of this study indicate that all dimensions of brand leadership have a positive and significant effect on repurchase intention. The popularity dimension has the most influence to drive repurchase intentions on e-commerce sites. Then, it is followed by the dimensions of quality, innovation, and value dimensions. The study notes that consumers have high opinions of leading brands even when these brands have not been proven to provide high-quality products. Online reviews and word of mouth can be used to increase and maintain popularity, which can build trust in the product.
\end{abstract}

Keywords: e-commerce, brand leadership, repurchase intention.

Copyright (c) 2021

Nuri Wiyono, Siti Abadiyah, Dwi Ferdiyatmoko Cahya Kumoro, Masduki Asbari, Dewiana Novitasari $\triangle$ Corresponding author:

Email : nwiyono.ip@gmail.com

DOI $\quad$ https://doi.org/10.31004/edukatif.v3i6.1542 
4690 Kepemimpinan Merek pada Website E-commerce: Analisis Pengaruhnya terhadap Niat Pembelian Ulang - Nuri Wiyono, Siti Abadiyah, Dwi Ferdiyatmoko Cahya Kumoro, Masduki Asbari, Dewiana Novitasari

DOI: https://doi.org/10.31004/edukatif.v3i6.1542

\section{PENDAHULUAN}

Perkembangan digital telah mengubah cara konsumen berperilaku. Tidak dapat dipungkiri bahwa saat ini masyarakat di dunia dan Indonesia telah banyak sekali melakukan pembelian secara online. Jumlah transaksinya pun dari tahun ke tahun semakin meningkat dan jenis barang yang masyarakat beli juga semakin beraneka ragam. Dari data survey yang dilakukan pada semester pertama 2019 yang dilakukan oleh jakpat, diketahui bahwa 60,5\% responden lebih memilih untuk melakukan aktivitas belanja secara online dibandingkan mengunjungi offline store. Alasan responden lebih memilih melakukan transaksi secara online adalah karena lebih cepat dan efisien $(65,7 \%)$, ada banyak promo dan diskon $(62,9 \%)$, harga yang bersaing bahkan cenderung lebih murah (59,3\%), dan fleksibilitas waktu berbelanja (59\%). Mengambil sumber dari laporan wearesocial.com pada Januari 2019, terdapat peningkatan jumlah masyrakat yang melakukan transaksi e-commerce sebesar 5.9\% dibandingkan dengan tahun sebelumnya dan hal ini juga masih dapat bertumbuh karena penetrasi pasar e-commerce di Indonesia juga masih cukup rendah, yakni sebesar $40 \%$ (Binus.ac.id, 2019).

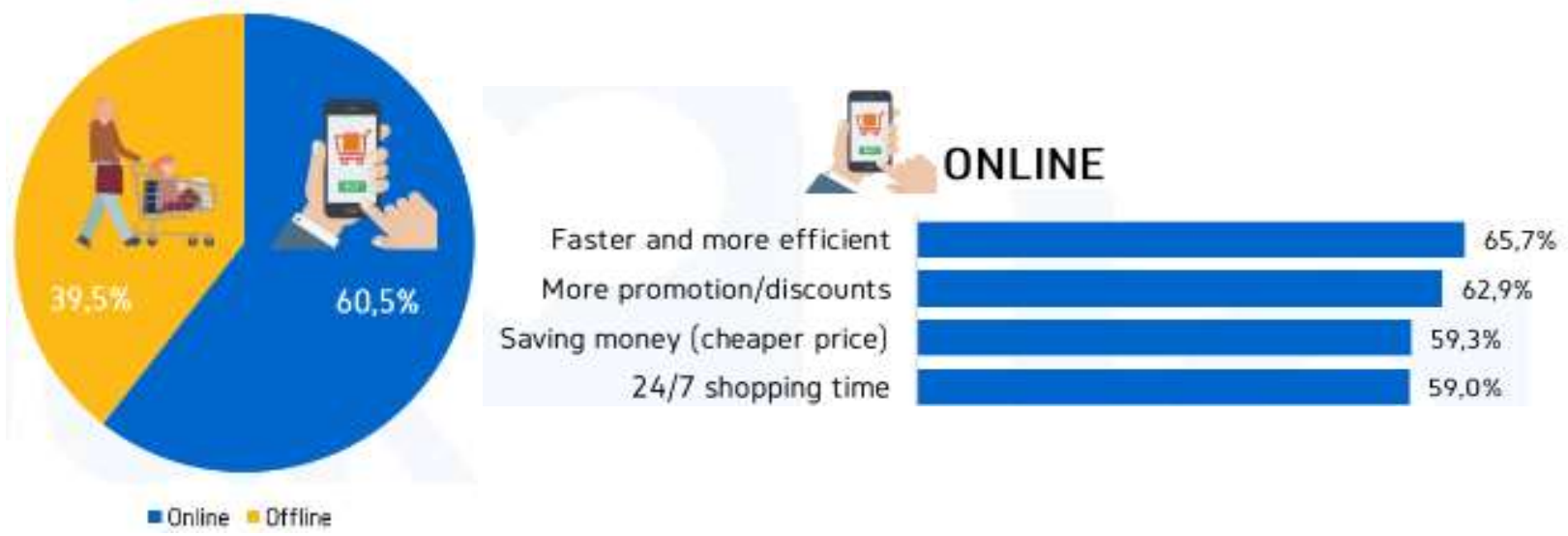

\section{Gambar 1. Perbadingan Pembelian Online dan Offline}

Sumber: Binus.ac.id (2019) (Diakses 10/10/2021)

Selain itu, penjualan e-ritel global menyumbang untuk 10,2 persen dari semua penjualan ritel di seluruh dunia pada tahun 2017, dan jumlah ini diperkirakan akan mencapai 17,5 persen pada tahun 2021 (Chiu \& Cho, 2019). Masih merujuk pada laporan dari wearesocial, bahwa terdapat peningkatan yang signifikan pada perilaku belanja online masyarakat Indonesia. Pertumbuhan tertinggi terdapat pada kategori makanan dan produk perawatan yakni sebesar 30\%, kedua adalah kategori produk mainan dan hobi sebesar 25\%, dan ketiga adalah pada kategori barang-barang elektronik sebesar 24\%. Namun dalam hal nilai transaksi, penjualan tertinggi terdapat pada kateogri online travel dengan nominal sebesar USD 9.376 milyar, lalu ada penjualan furniture sebesar USD 1.674 milyar serta mainan dan hobi sebesar USD 1.46 milyar. Melihat hasil data tersebut, maka dapat dilihat bahwa saat ini telah banyak masyarakat yang mulai beralih dari yang biasanya suka berbelanja kebutuhan rumah tangga dengan mengunjungi toko, sedikit demi sedikit beralih berbelanja kebutuhan rumah tangga secara online. Serta traveling dan membeli suatu mainan serta hobi sudah menjadi sebuah gaya hidup dan kebutuhan bagi masyarakat di Indonesia (Binus.ac.id, 2019).

Karena intensifikasi belanja online, perang e-commerce menjadi semakin intens, terutama di antara situs web e-niaga paling terkenal di AS, seperti Amazon, eBay, BestBuy, dan Target. Situs web e-niaga ini menawarkan kemudahan dan cara ekonomis bagi produsen atau pengecer untuk mendistribusikan barangbarang mereka secara lebih efektif dan menjangkau konsumen potensial (Garín-Muñoz et al., 2019). Sementara itu, konsumen memiliki lebih banyak pilihan dan lebih baik transaksi di situs web e-commerce 
4691 Kepemimpinan Merek pada Website E-commerce: Analisis Pengaruhnya terhadap Niat Pembelian Ulang - Nuri Wiyono, Siti Abadiyah, Dwi Ferdiyatmoko Cahya Kumoro, Masduki Asbari, Dewiana Novitasari

DOI: https://doi.org/10.31004/edukatif.v3i6.1542

yang berbeda. Dengan demikian, dari sudut pandang konsumen dan bisnis, sangat penting bagi manajer $e$ commerce dan akademisi untuk memahami saluran distribusi virtual ini (Tsagkias et al., 2021).

Selain itu, karena konsumen menjadi lebih paham teknologi, manajer e-commerce dan akademisi perlu memahami secara komprehensif kebutuhan konsumen dan faktor-faktor yang mempengaruhi keputusan mereka untuk memilih dan berbelanja di situs web e-commerce. Secara umum, ada dua tahap memahami perilaku konsumsi online. Pertama tahap concerns tentang bagaimana mendorong orang untuk membeli secara online; dan tahap kedua adalah untuk mendorong mereka untuk membeli kembali (repurchase), yang penting adalah bagaiaman mempertahankan pelanggan yang sudah pernah berkunjung ke website $e$ commerce. Biaya, waktu dan usahanya lebih sedikit untuk mempertahankan pelanggan yang sudah ada daripada untuk mendapatkan yang pelanggan baru. Pelanggan tetap ini menghabiskan lebih banyak uang untuk pembelian mereka dan menghasilkan lebih banyak profitabilitas daripada pelanggan baru (Chiu \& Cho, 2019).

Dengan demikian, bagaimana mempertahankan pelanggan yang sudah ada untuk membuat pembelian kembali menjadi perhatian utama untuk situs web e-commerce daripada waktu-waktu sebelumnya (Sullivan \& Kim, 2018). Namun, dikatakan bahwa tingkat pembelian kembali adalah indikator yang paling diabaikan untuk e-retailer. Selain itu, perlu dicatat bahwa hanya 32 persen dari pelanggan membeli kembali di situs web e-commerce yang sama di tahun pertama mereka (Chiu \& Cho, 2019).

Dengan demikian, situs web e-niaga yang berfokus pada atribut ini dapat menciptakan pengalaman belanja "bermerek" bagi konsumen (Mohseni et al., 2018). Sementara itu, konsumen menjadi lebih sadar akan nilai situs web e-commerce dan mengevaluasi berbagai atribut dan layanan disediakan oleh situs web $e$ commerce (Garín-Muñoz et al., 2019). Namun demikian, peran kepemimpinan merek yang dirasakan konsumen dari situs web e-commerce dalam pengalaman dan niat pembelian ulang masih belum diketahui. Oleh karena itu, tujuan utama dari studi ini adalah untuk menyelidiki pengaruh kepemimpinan merek yang dirasakan dari website e-commerce terhadap niat pembelian ulang. Penelitian ini mengeksplorasi dimensi kepemimpinan merek yang terdiri dari kualitas, nilai, inovasi dan popularitas. Penelitian ini nampaknya menjadi pioneer dalam studi yang sama dengan menjadikan mahasiswa perguruan tinggi sebagai subyek dan unit analisis.

Oleh karena itu, penting untuk mengidentifikasi faktor-faktor yang mempengaruhi perilaku pembelian ulang konsumen online. Studi sebelumnya telah meneliti berbagai faktor yang mempengaruhi konsumen online niat membeli kembali di situs web e-commerce. Ini termasuk nilai yang dirasakan, kualitas dan fungsionalitas situs web, inovasi dan popularitas (Chiu \& Cho, 2019). Faktor-faktor ini terutama mengeksplorasi persepsi dan atribut konsumen terhadap situs web e-commerce tertentu. Studi sebelumnya telah menemukan bahwa konsumen menganggap kepemimpinan merek mempengaruhi perilaku pengambilan keputusan mereka (Widiandita \& Ketut, 2020). Lebih khusus lagi, konsumen mungkin lebih memilih merek atau layanan terkemuka bukan hanya karena memberikan kualitas atau nilai yang lebih baik, tetapi juga karena mewakili citra diri (Chang \& Ko, 2014). Saat ini, lebih banyak platform e-commerce memungkinkan konsumen untuk menelusuri dan membandingkan berbagai platform e-commerce dengan mudah sebelum melakukan pembelian.

\section{METODE PENELITIAN}

Menurut Creswell \& Creswell (2017), jika tujuan dari penelitian ini adalah untuk mengetahui hubungan pengaruh antar variabel yang diteliti, maka pendekatan kuantitatif adalah yang terbaik. Metode penelitian kuantitatif adalah cocok dalam menguji teori dan hipotesis melalui penggunaan seperangkat alat statistik (Creswell \& Creswell, 2017). Oleh karena itu, penelitian ini menggunakan metode survei untuk menguji hipotesis yang dirumuskan. Oleh karena itu, diadopsi kuesioner digunakan sebagai instrumen untuk 
4692 Kepemimpinan Merek pada Website E-commerce: Analisis Pengaruhnya terhadap Niat Pembelian Ulang - Nuri Wiyono, Siti Abadiyah, Dwi Ferdiyatmoko Cahya Kumoro, Masduki Asbari, Dewiana Novitasari

DOI: https://doi.org/10.31004/edukatif.v3i6.1542

mengumpulkan data yang dibutuhkan. Populasi penelitian terdiri dari 1205 mahasiswa di perguruan tinggi swasta di Tangerang. Dengan menggunakan simple random sampling, 1205 kuesioner dikirim secara online kepada populasi. Sebanyak 1026 kuesioner dikembalikan dan valid, yang membentuk tingkat tanggapan $85,1 \%$. Oleh karena itu, manurut Roscoe et al. (1975) jumlah sampel yang diperoleh sudah sangat memadai.

Sifat penelitian ini melibatkan efek dependen antara konstruk laten dan variabel manifest, oleh karena itu, model pengukuran reflektif cocok untuk penelitian ini (Hair Jr et al., 2017). Semua item yang diadopsi dinilai pada skala Likert lima poin dari 1 (sangat tidak setuju) sampai 5 (sangat setuju). Instrumen kepemimpinan Merek (KM) terdiri dari empat dimensi, yakni kualitas terdiri dari 3 item (KUL1KUL3), nilai terdiri dari 3 item (NIL1-NIL3), inovasi terdiri dari 3 item (INO1-INO3), popularitas terdiri dari 3 item (POP1-POP3) diadaptasi dari Chang \& Ko (2014). Instrumen untuk mengukur niat pembelian ulang terdiri dari 3 item (NPU1-NPU3) mengadaptasi dari Chiu et al. (2014).

Teknik statistik paling populer di bawah Structural Equation Model SEM adalah berbasis kovarian pendekatan (CB-SEM) dan teknik kuadrat terkecil parsial berbasis varian (PLS-SEM) (Sarstedt et al., 2014). Namun, PLS-SEM akhir-akhir ini mendapat perhatian yang luas di banyak orang disiplin ilmu seperti pemasaran, manajemen strategis, sistem informasi manajemen, dan cabang keilmuan lainnya (Hair et al., 2012). Kemampuan PLS-SEM untuk menangani permasalahan problematic modelling yang biasa terjadi di lingkungan social ilmu pengetahuan seperti karakteristik data yang tidak biasa (misalnya data non-normal) dan model yang sangat kompleks adalah alasan penting di balik peningkatan penggunaan pendekatan ini. Mengingat keuntungan dari pendekatan ini, penelitian ini menggunakan PLS-SEM untuk menguji secara keseluruhan dari hipotesis yang diajukan. Perangkat lunak SmartPLS 3.0 dilakukan untuk mengevaluasi masing-masing outer model dan inner model. Pengujian outer model dilakukan untuk memastikan keandalan dan validitas pengukuran, sedangkan hipotesis yang diperkenalkan diperiksa melalui inner model. Selanjutnya, hasil akhir kuesioner yang kemudian digunakan pada penelitian ini sebagaimana disebutkan pada Tabel 1.

\section{Tabel 1}

Daftar Item Penelitian

\begin{tabular}{ll}
\hline Notasi & Item \\
\hline \multicolumn{2}{l}{} \\
\hline Kepemimpinan Merek (KM) \\
\hline Kualitas: & \\
\hline KUL1 & Situs belanja online ini memiliki standar kualitas yang lebih tinggi. \\
\hline KUL2 & Situs belanja online ini unggul dalam standar kualitas. \\
\hline KUL3 & Situs belanja online ini menawarkan fitur berkualitas lebih tinggi. \\
\hline Nilai: & \\
\hline NIL1 & Produk dari situs belanja online ini memiliki harga yang wajar. \\
\hline NIL2 & Produk dari situs belanja online ini memiliki manfaat yang lebih baik dari segi harga. \\
\hline NIL3 & Produk dari situs belanja online ini menawarkan lebih banyak manfaat untuk harganya. \\
\hline Inovasi: & \\
\hline INO1 & Situs belanja online ini lebih dinamis dalam perbaikan. \\
\hline INO2 & Situs belanja online ini lebih kreatif dalam produk dan layanan. \\
\hline INO3 & Situs belanja online ini lebih merupakan trendsetter. \\
\hline Popularitas: & \\
\hline POP1 & Situs belanja online ini lebih disukai. \\
\hline POP2 & Situs belanja online ini lebih dikenal. \\
\hline Niat Pembelian Ulang (NPU) \\
\hline NPU1 & Jika saya bisa, saya ingin terus menggunakan situs belanja online ini untuk membeli \\
\hline
\end{tabular}


4693 Kepemimpinan Merek pada Website E-commerce: Analisis Pengaruhnya terhadap Niat Pembelian Ulang - Nuri Wiyono, Siti Abadiyah, Dwi Ferdiyatmoko Cahya Kumoro, Masduki Asbari, Dewiana Novitasari

DOI: https://doi.org/10.31004/edukatif.v3i6.1542

\begin{tabular}{ll}
\hline & produk. \\
\hline NPU2 & Kemungkinan saya akan terus membeli produk dari situs belanja online ini di masa depan. \\
\hline NPU3 & Saya berniat untuk terus membeli produk dari situs belanja online ini. \\
\hline
\end{tabular}

Menurut Sekaran \& Bougie (2003) kerangka teoritis merupakan fondasi di mana seluruh proyek penelitian didasarkan. Dari kerangka teoritis bisa disusun hipotesis yang dapat diuji untuk mengetahui apakah teori yang dirumuskan valid atau tidak. Lalu kemudian selanjutnya akan dapat diukur dengan analisis statistik yang tepat. Untuk itu, penulis membangun model penelitian sebagai mana disebut pada Gambar 2 berikut:

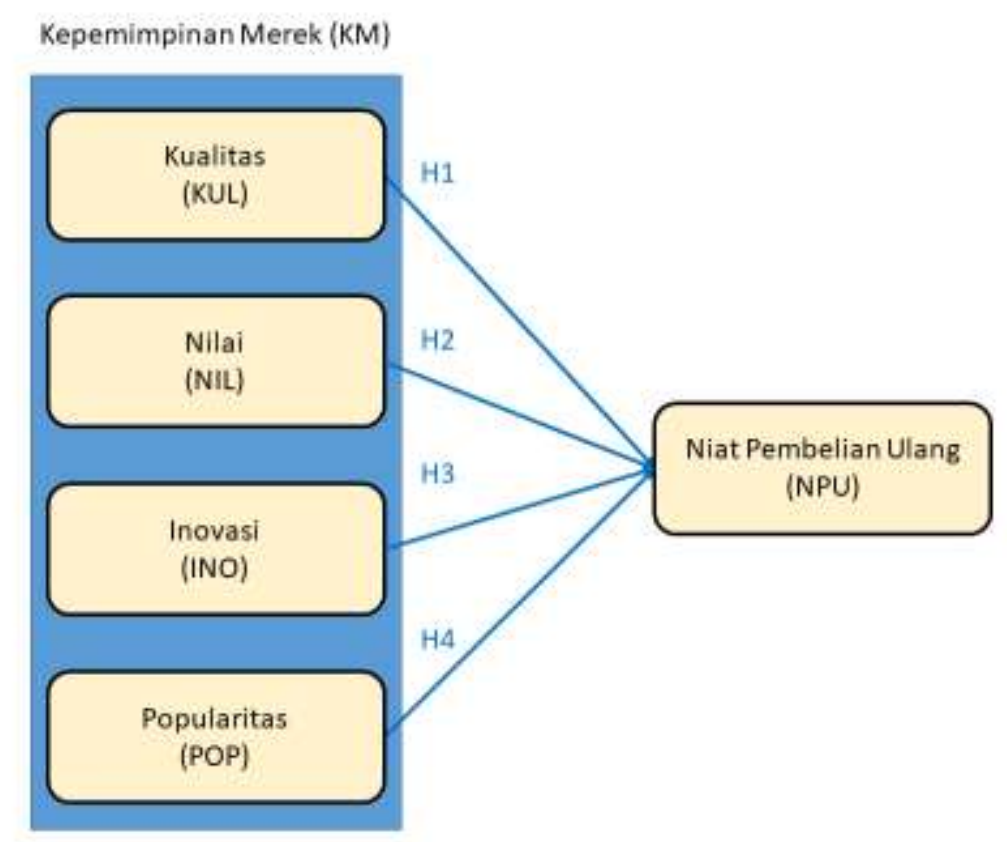

Gambar 2. Model Penelitian

Dalam nada yang sama, dimensi kepemimpinan merek yang dihargai konsumen online (missal: konten dan fungsi situs web) tidak hanya dapat meningkatkan kepuasan tetapi juga niat membeli kembali. Misalnya, (Owen, 2020) menemukan bahwa kepemimpinan merek yang dirasakan memiliki pengaruh yang signifikan terhadap promosi dari mulut ke mulut konsumen (WOM) niat dalam pengaturan layanan yang berbeda. Dengan demikian, penelitian ini menetapkan hipotesis sebagai berikut:

H1: Kualitas website e-commerce memiliki pengaruh positif terhadap niat pembelian ulang.

$\mathrm{H} 2$ : Persepsi nilai pada website e-commerce memiliki pengaruh positif terhadap niat pembelian ulang.

H3: Inovasi yang dirasakan pada website e-commerce memiliki pengaruh positif terhadap niat pembelian ulang.

H4: Popularitas yang dirasakan memiliki pengaruh positif terhadap niat pembelian kembali.

\section{HASIL DAN PEMBAHASAN PENELITIAN}

\section{Hasil Penelitian}

Total ada 1026 mahasiswa yang berpartisipasi, terdiri dari laki-laki (61\%) dan perempuan (39\%). Hampir seluruh responden memiliki kelompok umur yang seragam, yakni 17-24 tahun. Tahap pengujian model pengukuran meliputi pengujian validitas konvergen, validitas diskriminan. Sementara untuk menguji reliabilitas konstruk digunakan nilai cronbach's alpha dan composite reliability. Hasil analisis PLS dapat digunakan untuk menguji hipotesis penelitian jika seluruh indikator dalam model PLS telah memenuhi syarat validitas konvergen, validitas deskriminan dan uji reliabilitas. Uji validitas konvergen dilakukan dengan 
4694 Kepemimpinan Merek pada Website E-commerce: Analisis Pengaruhnya terhadap Niat Pembelian Ulang - Nuri Wiyono, Siti Abadiyah, Dwi Ferdiyatmoko Cahya Kumoro, Masduki Asbari, Dewiana Novitasari

DOI: https://doi.org/10.31004/edukatif.v3i6.1542

melihat nilai loading factor masing-masing indikator terhadap konstruknya. Pada sebagian besar referensi, bobot faktor sebesar 0,7 atau lebih dianggap memiliki validasi yang cukup kuat untuk menjelaskan konstruk laten (Chin, 1998; Ghozali, 2014; J. F. Hair et al., 2010). Pada penelitian ini batas minimal besarnya loading factor yang diterima adalah 0,7, dan dengan syarat nilai AVE setiap konstruk > 0,5 (Ghozali, 2014). Setelah melalui pengolahan SmartPLS 3.0, seluruh indikator telah memiliki nilai loading factor di atas 0,7 dan nilai AVE di atas 0,5. Model fit atau valid dari penelitian ini dapat dilihat pada Gambar 2. Jadi dengan demikian, validitas konvergen dari model penelitian ini sudah memenuhi syarat (Purwanto et al., 2019, 2020; Purwanto, Asbari, \& Santoso, 2021b, 2021a; Purwanto, Asbari, Santoso, et al., 2021). Nilai loadings, cronbach's alpha, composite reliability dan AVE setiap konstruk selengkapnya dapat dilihat Tabel 2.

Discriminant validity dilakukan untuk memastikan bahwa setiap konsep dari masing-masing variabel laten berbeda dengan variabel laten lainnya. Model mempunyai discriminant validity yang baik jika nilai kuadrat AVE masing-masing konstruk eksogen (nilai pada diagonal) melebihi korelasi antara konstruk tersebut dengan konstruk lainnya (nilai di bawah diagonal) (Ghozali, 2014). Hasil pengujian discriminant validity adalah dengan menggunakan nilai kuadrat AVE, yakni dengan melihat Fornell-Larcker Criterion Value diperoleh sebagaimana ditunjukkan pada Tabel 3. Hasil uji validitas deskriminan pada tabel 3 menunjukkan bahwa seluruh konstruk telah memiliki nilai akar kuadrat AVE di atas nilai korelasi dengan konstruk laten lainnya (melalui kriteria Fornell-Larcker). Demikian juga nilai cross-loading seluruh item dari suatu indikator lebih besar dari item indikator lainnya sebagaimana disebut pada Tabel 3, sehingga dapat disimpulkan bahwa model telah memenuhi validitas deskriminan (Fornell \& Larcker, 1981).

Selanjutnya dilakukan evaluasi collinearity untuk mengetahui ada tidaknya masalah collinearity pada model. Untuk menemukan collinearity tersebut, diperlukan statistik collinearity VIF dari setiap konstruk. Jika VIF lebih dari 5, maka model memiliki collinearity (Hair et al., 2014). Seperti yang ditunjukkan pada Tabel 4, semua skor VIF kurang dari 5, yakni hasil dari model struktural collinearity mengungkapkan nilai VIF di bawah 2. Hal ini menunjukkan bahwa model penelitian ini tidak ada masalah multikolinearitas.

Reliabilitas konstruk dapat dinilai dari nilai cronbach's alpha dan composite reliability dari masingmasing konstruk. Nilai composite reliability dan cronbach's alpha yang disarankan adalah lebih dari 0,7 (Ghozali, 2014). Hasil uji reliabilitas pada tabel 2 menunjukkan bahwa seluruh konstruk telah memiliki nilai composite reliability dan cronbach's alpha lebih besar dari $0,7(>0,7)$. Kesimpulannya, seluruh konstruk telah memenuhi reliabilitas yang dipersyaratkan.

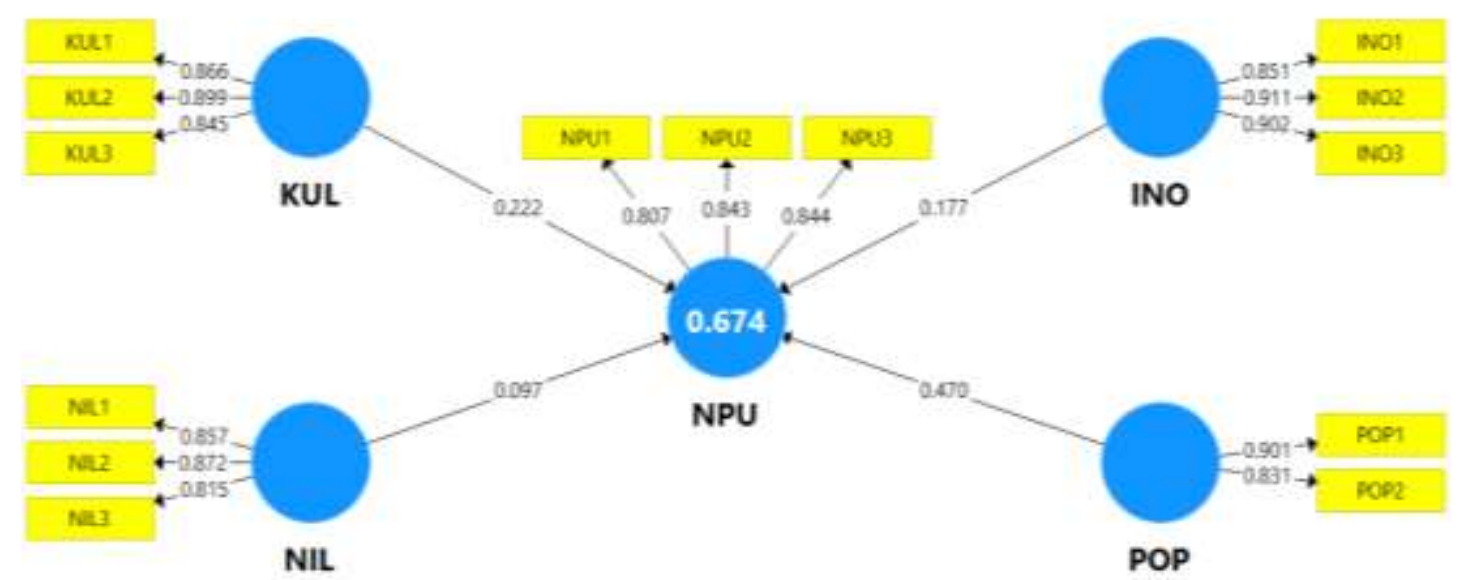

Gambar 2. Model Penelitian Valid

Sumber: Hasil Pengolahan SmartPLS 3.0 (2021) 
4695 Kepemimpinan Merek pada Website E-commerce: Analisis Pengaruhnya terhadap Niat Pembelian Ulang - Nuri Wiyono, Siti Abadiyah, Dwi Ferdiyatmoko Cahya Kumoro, Masduki Asbari, Dewiana Novitasari

DOI: https://doi.org/10.31004/edukatif.v3i6.1542

Tabel 2

Items Loadings, Cronbach's Alpha, Composite Reliability, and Average Variance Extracted (AVE)

\begin{tabular}{|c|c|c|c|c|c|c|}
\hline Variables & Items & Loadings & $\begin{array}{l}\text { Cronbach's } \\
\text { Alpha }\end{array}$ & Rho_A & $\begin{array}{l}\text { Composite } \\
\text { Reliability }\end{array}$ & AVE \\
\hline \multirow[t]{3}{*}{$\begin{array}{l}\text { Kepemimpinan Merek: Kualitas } \\
\text { (KUL) }\end{array}$} & KUL1 & 0,866 & 0,840 & 0,840 & 0,904 & 0,758 \\
\hline & KUL2 & 0,899 & & & & \\
\hline & KUL3 & 0,845 & & & & \\
\hline \multirow[t]{3}{*}{ Kepemimpinan Merek: Nilai (NIL) } & NIL1 & 0,857 & 0,805 & 0,807 & 0,885 & 0,720 \\
\hline & NIL2 & 0,872 & & & & \\
\hline & NIL3 & 0,815 & & & & \\
\hline \multirow[t]{3}{*}{$\begin{array}{l}\text { Kepemimpinan Merek: Inovasi } \\
\text { (INO) }\end{array}$} & INO1 & 0,851 & 0,866 & 0,867 & 0,918 & 0,789 \\
\hline & INO2 & 0,911 & & & & \\
\hline & INO3 & 0,902 & & & & \\
\hline \multirow[t]{2}{*}{$\begin{array}{l}\text { Kepemimpinan Merek: Popularitas } \\
\text { (POP) }\end{array}$} & POP1 & 0,901 & 0,674 & 0,702 & 0,858 & 0,751 \\
\hline & POP2 & 0,831 & & & & \\
\hline \multirow[t]{3}{*}{ Niat Pembelian Ulang (NPU) } & NPU1 & 0,807 & 0,777 & 0,782 & 0,870 & 0,691 \\
\hline & NPU2 & 0,843 & & & & \\
\hline & NPU3 & 0,844 & & & & \\
\hline
\end{tabular}

Sumber: Hasil Pengolahan SmartPLS 3.0 (2021)

Tabel 3

Discriminant Validity

\begin{tabular}{llllll}
\hline Variables & INO & KUL & NIL & NPU & POP \\
\hline INO & 0,888 & & & & \\
\hline KUL & 0,484 & 0,870 & & & \\
\hline NIL & 0,565 & 0,615 & 0,848 & & \\
\hline NPU & 0,579 & 0,678 & 0,625 & 0,831 & 0,867 \\
\hline POP & 0,511 & 0,663 & 0,620 & 0,767 & \\
\hline
\end{tabular}

Sumber: Hasil Pengolahan SmartPLS 3.0 (2021)

Tabel 4

Collinearity (VIF)

\begin{tabular}{|c|c|c|c|c|c|}
\hline Variables & INO & KUL & NIL & NPU & POP \\
\hline INO & & & & 1,584 & \\
\hline KUL & & & & 2,054 & \\
\hline NIL & & & & 2,053 & \\
\hline \multicolumn{6}{|c|}{$\mathrm{NPU}$} \\
\hline POP & & & & & \\
\hline
\end{tabular}

Sumber: Hasil Pengolahan SmartPLS 3.0 (2021)

Tabel 5

Nilai $R$ Square

\begin{tabular}{lcc}
\hline Variables & R Square & R Square Adjusted \\
\hline NPU & 0,674 & 0,673 \\
\hline
\end{tabular}

Sumber: Hasil Pengolahan SmartPLS 3.0 (2021) 
4696 Kepemimpinan Merek pada Website E-commerce: Analisis Pengaruhnya terhadap Niat Pembelian Ulang - Nuri Wiyono, Siti Abadiyah, Dwi Ferdiyatmoko Cahya Kumoro, Masduki Asbari, Dewiana Novitasari

DOI: https://doi.org/10.31004/edukatif.v3i6.1542

Tabel 6

Hypotheses Testing

\begin{tabular}{llllllll}
\hline Hypotheses & Relationship & $\begin{array}{l}\text { Original } \\
\text { Sample } \\
(\mathrm{O})\end{array}$ & $\begin{array}{l}\text { Sample } \\
\text { Mean } \\
(\mathrm{M})\end{array}$ & $\begin{array}{l}\text { Standard } \\
\text { Deviation } \\
(\mathrm{STDEV})\end{array}$ & $\begin{array}{l}\text { T Statistics } \\
(|\mathrm{O} / \mathrm{STDEV}|)\end{array}$ & P Values & Decision \\
\hline $\mathrm{H} 1$ & KUL -> NPU & 0,222 & 0,220 & 0,030 & 7,508 & 0,000 & Didukung \\
\hline $\mathrm{H} 2$ & NIL -> NPU & 0,097 & 0,101 & 0,030 & 3,225 & 0,001 & Didukung \\
\hline H3 & INO -> NPU & 0,177 & 0,176 & 0,025 & 7,032 & 0,000 & Didukung \\
\hline H4 & POP -> NPU & 0,470 & 0,471 & 0,030 & 15,549 & 0,000 & Didukung
\end{tabular}

Sumber: Hasil Pengolahan SmartPLS 3.0 (2021)

Pengujian hipotesis dalam PLS disebut juga sebagai uji inner model. Uji ini meliputi uji signifikansi pengaruh langsung dan tidak langsung serta pengukuran besarnya pengaruh variabel eksogen terhadap variabel endogen. Untuk mengetahui pengaruh empat dimensi kepemimpinan Merek yang terdiri kualitas, nilai, inovasi dan popularitas terhadap niat pembelian ulang dibutuhkan uji pengaruh langsung. Uji pengaruh dilakukan dengan menggunakan uji t-statistik dalam model analisis partial least squared (PLS) dengan menggunakan bantuan software SmartPLS 3.0, Dengan teknik boothstrapping, diperoleh nilai $R$ Square dan nilai uji signifikansi sebagaimana Tabel 5 dan Tabel 6. Hasilnya adalah semua hipotesis $(\mathbf{H 1}, \mathbf{H 2}, \mathbf{H 3}, \mathbf{H 4})$ di dukung.

\section{Pembahasan Penelitian}

Tujuan utama dari penelitian ini adalah untuk menyelidiki pengaruh kepemimpinan merek terhadap niat pembelian ulang di situs e-commerce. Hasil studi ini menyebutkan bahwa semua dimensi kepemimpinan merek ditemukan positif mempengaruhi niat pembelian kembali. Pembahasan berikut menguraikan pengaruh masing-masing dimensi kepemimpinan merek terhadap niat pembelian kembali.

Telah dicatat bahwa, di kalangan mahasiswa, dimensi popularitas memiliki pengaruh paling besar $(0,470)$ untuk mendorong niat pembelian ulang di situs e-commerce. Kemudian diikuti oleh dimensi kualitas, inovasi dan nilai situs e-commerce. Temuan ini mendukung kesimpulan penelitian sebelumnya yang dilakukan oleh Chiu \& Cho (2019) bahwa popularitas dan nilai berpengaruh positif dan signifikan terhadap niat pembelian ulang di situs e-commerce. Uniknya, studi ini dan penelitian Chiu \& Cho (2019) menemukan kesamaan hasil, yakni dimensi popularitas menempati posisi pemberi pengaruh paling kuat terhadap niat pembelian ulang.

Temuan unik pada studi ini mengkonfirmasi bahwa dimensi popularitas dari kepemimpinan merek merek berpotensi menyimpangkan konsumen dari nilai sebenarnya dan mengarahkan mereka pada manfaat seperti harga diri dan nilai social. Ini menunjukkan bahwa pengakuan sosial terhadap merek dan penghargaan positif mendorong mereka untuk membeli produk populer (Chang \& Ko, 2014). Studi ini mencatat bahwa konsumen memiliki opini yang tinggi terhadap merek-merek terkemuka bahkan ketika merek tersebut tidak terbukti memberikan produk berkualitas tinggi. Ulasan online atau ulasan dari mulut-ke mulut dapat digunakan untuk meningkatkan dan mempertahankan popularitas, yang dapat membangun kepercayaan terhadap produk.

Walaupun demikian, penelitian ini berbeda hasil dengan temuan Chiu \& Cho (2019). Pada penelitian Chiu \& Cho (2019), dimensi kualitas dan inovasi tidak berpengaruh positif dan signifikan terhadap niat pembelian ulang, sedangkan penelitian ini menemukan fakta bahwa keempat dimensi kepemimpinan merek memberikan pengaruh yang positif dan signifikan, dengan tingkat signifikansi yang berbeda. Studi ini membuktikan bahwa persepsi mahasiswa dalam menilai situs e-commerce lebih holistic dan menyeluruh. 
4697 Kepemimpinan Merek pada Website E-commerce: Analisis Pengaruhnya terhadap Niat Pembelian Ulang - Nuri Wiyono, Siti Abadiyah, Dwi Ferdiyatmoko Cahya Kumoro, Masduki Asbari, Dewiana Novitasari

DOI: https://doi.org/10.31004/edukatif.v3i6.1542

Dalam persepsi responden studi ini, popularitas memang menempati urutan teratas, tapi responden tetap menilai perlunya factor-faktor atau dimensi-dimensi kepemimpinan merek lain yang harus terlibat dengan baik.

Hal ini menunjukkan bahwa konsumen dapat mempertimbangkan untuk melakukan pembelian ulang, tatkala situs e-commerce dinilai lebih popular di kalangan mahasiswa. Mahasiswa merasakan engage terhadap produk yang dijual pada e-commerce yang memiliki popularitas terbaik. Demikian juga dimensi kualitas, menempatkan prioritas lebih tinggi ketimbang dimensi nilai, sehingga responden siap membayar lebih sedikit untuk kualitas yang tinggi. Jadi responden konsumen termotivasi untuk mengulangi pembelian kembali ketika manfaat dari suatu produk lebih banyak dirasakan.

Implikasi praksis dari temuan studi ini adalah bahawa untuk menarik konsumen yang tidak paham teknologi, promosi dari mulut ke mulut adalah pemasaran yang bagus dan merupakan alat pemasaran yang efektif untuk membangun popularitas. Tentu tetap harus diikuti oleh kualitas dan inovasi yang memadai. Oleh karena itu, ketika penyedia layanan memastikan dimensi popularitas ini berkembang baik, maka bisa mendorong konsumen untuk beralih dari offline ke toko online, menganggap pembeliannya sebagai yang sikap mengikuti trend terkini, menjadi trendsetter.

Namun demikian, penelitian ini juga bukannya tanpa batasan. Studi ini di masa depan perlu melibatkan factor jenis kelamin dan usi responden, sehingga bisa memtakan lebih detil setiap pengaruh dari dimensi kepemimpinan merek yang ada. Bisa jadi, temuan studi ini akan mengungkap fakta-fakta baru yang lebih rinci dan bermanfaat bagi perkembangan bisnis e-commerce di masa depan. Dimungkinkan juga untuk memperluas model teoritis studi ini dengan memasukkan variabel dependen tambahan seperti kepuasan konsumen dan budaya masyarakat.

\section{KESIMPULAN}

Akhirnya, temuan studi ini mengonfirmasi bahwa seluruh dimensi kepemimpinan merek, yang terdiri dari dimensi kualitas, nilai, inovasi dan popuilaritas memberikan pengaruh yang positif dan signifikan terhadap niat atau keinginan untuk melakukan pembelian ulang pada produk yang dipasarkan di situs ecommerce. Temuan dan implikasi dari studi ini sebagian besar sejalan dengan literatur yang ada, yang telah dibahas sebelumnya.

\section{DAFTAR PUSTAKA}

Binus.ac.id. (2019). Perilaku Belanja Online di Indonesia. 23 Aug 2019. https://binus.ac.id/bandung/2019/08/perilaku-belanja-online-di-indonesia/

Chang, Y., \& Ko, Y. J. (2014). The brand leadership: Scale development and validation. Journal of Brand Management, 21(1), 63-80. https://doi.org/10.1057/bm.2013.23

Chin, W. (1998). The Partial Least Squares Approach to Structural Equation Modeling (E. Modern Methods for Business Research, In: G. A. Marcoulides (ed.)). Lawrence Erlbaum Associates Publisher.

Chiu, C. M., Wang, E. T. G., Fang, Y. H., \& Huang, H. Y. (2014). Understanding customers' repeat purchase intentions in B2C e-commerce: The roles of utilitarian value, hedonic value and perceived risk. Information Systems Journal, 24(1), 85-114. https://doi.org/10.1111/j.1365-2575.2012.00407.x

Chiu, W., \& Cho, H. (2019). E-commerce brand: The effect of perceived brand leadership on consumers' satisfaction and repurchase intention on e-commerce websites. Asia Pacific Journal of Marketing and Logistics, 33(6), 1339-1362. https://doi.org/10.1108/APJML-10-2018-0403

Creswell, J. W., \& Creswell, J. D. (2017). Research design: Qualitative, quantitative, and mixed methods approaches. Sage publications. 
4698 Kepemimpinan Merek pada Website E-commerce: Analisis Pengaruhnya terhadap Niat Pembelian Ulang - Nuri Wiyono, Siti Abadiyah, Dwi Ferdiyatmoko Cahya Kumoro, Masduki Asbari, Dewiana Novitasari

DOI: https://doi.org/10.31004/edukatif.v3i6.1542

Fornell, C., \& Larcker, D. F. (1981). Evaluating Structural Equation Models with Unobservable Variables and Measurement Error. Journal of Marketing Research, 18(1), 39. https://doi.org/10.2307/3151312

Garín-Muñoz, T., López, R., Pérez-Amaral, T., Herguera, I., \& Valarezo, A. (2019). Models for individual adoption of eCommerce, eBanking and eGovernment in Spain. Telecommunications Policy, 43(1), 100 111.

Ghozali, I. (2014). Structural Equation Modeling, Metode Alternatif dengan Partial Least Square (PLS) (4th ed.). Badan Penerbit Universitas Diponegoro.

Hair, J. F., Black, W. C., Babin, B. J., \& Anderson, R. E. (2010). Multivariate Data Analysis (7th ed.). Pearson Prentice Hall.

Hair, Joe F, Sarstedt, M., Ringle, C. M., \& Mena, J. A. (2012). An assessment of the use of partial least squares structural equation modeling in marketing research. Journal of the Academy of Marketing Science, 40(3), 414-433.

Hair Jr, J. F., Sarstedt, M., Ringle, C. M., \& Gudergan, S. P. (2017). Advanced issues in partial least squares structural equation modeling. saGe publications.

Owen, J. (2020). Peran Brand Trust dan Online Brand Community Trust serta Mediasi Rerpurchase Intention dalam Mempengaruhi Positive EWOM Intention pada Perusahaan E-Commerce Tokopedia. Universitas Pelita Harapan.

Purwanto, A., Asbari, M., \& Santoso, T. I. (2021a). Analisis Data Penelitian Manajemen Pendidikan: Perbandingan Hasil antara Amos, SmartPLS, WarpPLS, dan SPSS untuk Jumlah Sampel Kecil. International Journal of Social, Policy and Law (IJOSPL), 01(01), 111-122.

https://ijospl.org/index.php/ijospl/article/view/64

Purwanto, A., Asbari, M., \& Santoso, T. I. (2021b). Education Management Research Data Analysis: Comparison of Results between Lisrel, Tetrad, GSCA, Amos, Smartpls, Warppls, And SPSS for Small Samples. Nidhomul Haq: Jurnal Manajemen Pendidikan Islam, 6(2), 382-399.

https://e-journal.ikhac.ac.id/index.php/nidhomulhaq/article/view/1575

Purwanto, A., Asbari, M., Santoso, T. I., Haque, M. G., \& Nurjaya. (2019). Marketing Research Quantitative Analysis for Large Sample: Comparing of Lisrel, Tetrad, GSCA, Amos, SmartPLS, WarpPLS, and SPSS. Jurnal Ilmiah Ilmu Administrasi Publik: Jurnal Pemikiran Dan Penelitian Administrasi Publik, 9(2), 355-372. https://ojs.unm.ac.id/iap/article/view/22803

Purwanto, A., Asbari, M., Santoso, T. I., Paramarta, V., \& Sunarsih, D. (2020). Social and Management Research Quantitative Analysis for Medium Sample: Comparing of Lisrel, Tetrad, GSCA, Amos, SmartPLS, WarpPLS, and SPSS. Jurnal Ilmiah Ilmu Administrasi Publik: Jurnal Pemikiran Dan Penelitian Administrasi Publik, 9(2), 518-532. https://ojs.unm.ac.id/iap/article/view/22804

Purwanto, A., Asbari, M., Santoso, T. I., Sunarsi, D., \& Ilham, D. (2021). Education Research Quantitative Analysis for Little Respondents: Comparing of Lisrel, Tetrad, GSCA, Amos, SmartPLS, WarpPLS, and SPSS. Jurnal Studi Guru Dan Pembelajaran, 4(2), 335-350. https://e-journal.my.id/jsgp/article/view/1326

Roscoe, A. M., Lang, D., \& Sheth, J. N. (1975). Follow-up Methods, Questionnaire Length, and Market Differences in Mail Surveys: In this experimental test, a telephone reminder produced the best response rate and questionnaire length had no effect on rate of return. Journal of Marketing, 39(2), 20-27.

Sarstedt, M., Ringle, C. M., Smith, D., Reams, R., \& Hair Jr, J. F. (2014). Partial least squares structural equation modeling (PLS-SEM): A useful tool for family business researchers. Journal of Family Business Strategy, 5(1), 105-115.

Sekaran, U., \& Bougie, R. (2003). Research Methods For Business: A Skill Building Approach (Sixth edit). John Wiley and Sons, Inc. 
4699 Kepemimpinan Merek pada Website E-commerce: Analisis Pengaruhnya terhadap Niat Pembelian Ulang - Nuri Wiyono, Siti Abadiyah, Dwi Ferdiyatmoko Cahya Kumoro, Masduki Asbari, Dewiana Novitasari

DOI: https://doi.org/10.31004/edukatif.v3i6.1542

Sullivan, Y. W., \& Kim, D. J. (2018). Assessing the effects of consumers' product evaluations and trust on repurchase intention in e-commerce environments. International Journal of Information Management, 39, 199-219.

Tsagkias, M., King, T. H., Kallumadi, S., Murdock, V., \& de Rijke, M. (2021). Challenges and research opportunities in ecommerce search and recommendations. ACM SIGIR Forum, 54(1), 1-23.

Widiandita, B. K., \& Ketut, G. I. A. (2020). The effect of perceived brand leadership towards consumer satisfaction and repurchase intention on e-commerce website. Russian Journal of Agricultural and Socio-Economic Sciences, 97(1). 